\title{
PENTINGNYA PERHITUNGAN BIAYA PRODUKSI UNTUK PENENTUAN HARGA JUAL PRODUK ANEKA KRIPIK
}

\author{
Jeanne Asteria Wawolangi ${ }^{1 *}$, Anita Permatasari ${ }^{2 *}$ \\ ${ }^{1,2}$ Program Studi Akuntansi, Fakultas Ekonomi, Universitas Katolik Darma Cendika \\ Jalan Dr. Ir. H. Soekarno 201, Surabaya \\ *Corresponding Author: jeanneasteria@gmail.com¹, an_n1t4@yahoo.com²
}

\begin{abstract}
The micro business is a marginal business type characterized by the use of relatively simple technology, a relatively small nominal level of capital, low access to credit, and oriented towards local market needs. General problem faced in managing this business is the calculation of product costs, which are usually only calculated simply based on the purchase price of raw materials, while direct production costs, because what is important is the smooth sale of these products. This study aims to assist micro-entrepreneurs in determining product costs, making it easier for business actors to determine the selling price of their products. This study uses a qualitative method.
\end{abstract}

Keywords: product cost, product selling price.

\begin{abstract}
ABSTRAK
Unit usaha mikro merupakan jenis usaha marginal yang ditandai dengan penggunaaan teknologi yang relatif sederhana, tingkat modal yang relatif kecil nominalnya, akses kredit yang rendah, dan berorientasi pada kebutuhan pasar lokal. Permasalahan yang sering dihadapi dalam mengelola usaha ini adalah perhitungan biaya produk, biasanya diperhitungkan secara sederhana berdasarkan harga beli bahan baku, sedangkan biaya tenaga kerja langsung, dan biaya produksi tidak langsung tidak diperhitungkan. Hal ini disebabkan karena yang dipentingkan adalah kelancaran penjualan produk tersebut. Penelitian ini mempunyai tujuan untuk membantu pelaku usaha mikro dalam menentukan biaya produk sehingga memudahkan para pelaku usaha dalam menentukan harga jual produknya. Penelitian ini menggunakan metode kualitatif.
\end{abstract}

Kata kunci: biaya produk, harga jual produk.

\section{PENDAHULUAN}

Pengembangan ekonomi sektor mikro perlu mendapat perhatian khusus dari pemerintah tanpa terkecuali, mengingat bahwa usaha mikro ini sangat besar 
jumlahnya. Pemerintah perlu memberikan dukungan dan bantuan agar usah mikro ini dapat berkembang menjadi usaha kecil dan menengah. Usaha mikro ini kebanyakan berupa home industry. Home industry dapat berfungsi untuk meningkatkan efisiensi ekonomi khususnya dalam menyerap sumber daya yang ada. Home industry juga dapat digunakan sebagai sarana pendistribusian pendapatan nasional, sehingga pemerintah perlu menjembatani home industry agar dapat bersaing secara kompetitif dan memudahkan jaringan distribusi penjualan untuk home industry (Kusuma, 2012).

Home industry Arumanis merupakan usaha industri kecil yang memproduksi aneka macam kripik yaitu kripik pisang, singkong, telo rambat, sukun, carang mas yang terbuat dari telo rambat, nangka, sukun, dan rengginang. Adapun bahan baku produk-produk yang dijual tersebut mudah diperoleh dan tersedia bahkan melimpah didaerah Trawas, terutama buah pisang, ketela rambat, singkong, nangka, dan sukun. Bahan baku yang digunakan oleh home industry Arumanis tidak dapat bertahan lama karena cepat rusak, sehingga munculah ide agar buah pisang, nangka, sukun, singkong, dan ketela rambat tersebut dapat bertahan lama serta mempunyai nilai tambah yang cukup tinggi maka dibuat menjadi kripik sebagai snack atau makanan ringan yang relatif tahan lama.

Proses pembuatan produk aneka kripik masih dengan peralatan yang sederhana, begitu juga perhitungan biaya produksi yang belum tepat. Pembebanan biaya produk hanya diperhitungkan biaya bahan baku saja sedangkan biaya tenaga kerja langsung dan biaya produksi tidak langsung hanya berupa taksiran saja. Hal ini disebabkan karena dapat mengakibatkan tingginya harga jual serta akan berpengaruh padahal volume penjualan, mengingat saat ini ada banyak kompetitor. Kurang tepatnya penentuan harga pokok produksi juga akan mempengaruhi pengambilan keputusan manajemen (Mulyadi, 2012: 23). Salah satu cara untuk dapat menarik konsumen, maka produk kripik ini dikemas dengan rapi dan menarik dengan menggunakan plastik khusus (tahan retak atau hancur) serta diberi label Arumanis dengan teknologi yang sederhana.

Produk kripik merk Arumanis menjadi makanan kecil atau snack yang banyak penggemarnya karena rasanya yang khas, gurih, serta lezat. Upaya memasarkan produk kripik tersebut dengan cara menitipkan melalui toko-toko kecil, pasar buah dan supermarket tertentu di daerah kawasan Trawas. Unit usaha kripik merk Arumanis merupakan usaha mikro yang tergolong jenis usaha marginal yang ditandai dengan penggunaaan teknologi yang sederhana, tingkat modal yang kecil nominalnya, akses kredit yang rendah, dan hanya berorientasi pada kebutuhan pasar lokal.

Permasalahan yang dihadapi oleh home industry Arumanis adalah kurang tepatnya perhitungan harga pokok produk yang biasanya hanya diperhitungkan secara sederhana saja berdasarkan harga beli bahan baku berupa buah pisang, nangka, sukun, ketela rambat, singkong, sedangkan biaya tenaga kerja langsung tidak diperhitungkan dan juga biaya produksi tidak langsung, karena yang dipentingkan adalah kelancaran penjualan produk kripik tersebut. Pemilik usaha Arumanis juga tidak melakukan pencatatan atas biaya-biaya yang dikeluarkan sehubungan dengan aktivitas produksi aneka kripik tersebut. Hal ini akan menyulitkan untuk menentukan harga jual produk yang tepat dan mengetahui posisi 
keuangan yang riil. Penentuan harga jual produk kripik tersebut hanya berdasarkan taksiran saja dan berdasarkan harga yang berlaku di pasar. Oleh karena itu, peneliti ingin melakukan perhitungan biaya produksi agar memudahkan pelaku bisnis mengetahui biaya produksi yang tepat sebagai dasar penetapan harga jual dan dapat mengambil keputusan keuangan yang lebih akurat.

\section{TINJAUAN PUSTAKA}

\section{Pengertian Usaha Mikro, Kecil , dan Menengah}

Menurut Juliprijanto dan Prasetyanto (2020) pembangunan dan pertumbuhan usaha kecil dan menengah (UKM) merupakan salah satu motor penggerak pertumbuhan ekonomi. Pada umumnya masalah-masalah yang dihadapi oleh usaha kecil dan menengah adalah pemasaran, modal, pendanaan, inovasi, pemanfaatan teknologi informasi, pemakaian bahan baku, peralatan produksi, penyerapan, dan tatanan lingkungan eksternal. Faktor yang dapat mempengaruhi keberhasilan usaha kecil dapat dikelompokkan menjadi dua yaitu faktor eksternal dan faktor internal. Faktor eksternal merupakan peran pemerintah dalam menciptakan lingkungan usaha yang kondusif bagi pertumbuhan usaha kecil sedangkan faktor internal meliputi karakteristik pemilik atau pengusaha atau pelaku bisnis (Sarwoko, 2017).

Menurut Undang-Undang Republik Indonesia Nomor 20 Tahun 2008 tentang Usaha Mikro, Kecil, dan Menengah, usaha mikro adalah usaha produktif milik orang-perorangan dan atau badan usaha perorangan yang memenuhi kriteria sebagai berikut:

1. Memiliki kekayaan bersih paling banyak sebesar Rp. 50.000.000,- tidak termasuk tanah dan bangunan tempat usaha; atau

2. Memiliki hasil penjualan tahunan paling banyak sebesar Rp. 300.000.000,-Usaha mikro merupakan jenis usaha marginal dengan pengunaan teknologi yang relatif sederhana, tingkat modal, dan akses terhadap kredit yang rendah, serta cenderung berorientasi pada pasar lokal, sedangkan usaha kecil menurut UndangUndang Republik Indonesia Nomor 20 Tahun 2008 tentang Usaha Mikro, Kecil, dan Menengah adalah usaha ekonomi produktif yang berdiri sendiri, yang dilakukan oleh orang perorangan atau badan usaha yang bukan merupakan anak perusahaan atau bukan cabang perusahaan yang dimiliki, dikuasai, atau menjadi bagian baik langsung maupun tidak langsung dari usaha menengah atau usaha besar yang memenuhi kriteria sebagai berikut:

1. Memiliki kekayaan bersih lebih dari Rp. 50.000.000,- sampai dengan paling banyak sebesar Rp. 500.000.000,- tidak termasuk tanah dan bangunan tempat usaha; atau

2. Memiliki hasil penjualan tahunan lebih dari Rp. 300.000.000,- sampai dengan paling banyak sebesar Rp. 2.500.000.000,-.

Usaha kecil merupakan usaha yang integral dalam dunia usaha nasional yang memiliki kedudukan, potensi, dan peranan yang signifikan dalam mewujudkan tujuan pembangunan nasional pada umumnya dan pembangunan ekonomi pada khususnya.

Pengertian usaha menengah menurut Undang-Undang Republik Indonesia Nomor 20 Tahun 2008 tentang Usaha Mikro, Kecil, dan Menengah adalah usaha ekonomi produktif yang berdiri sendiri, yang dilakukan oleh orang perorangan atau 
badan usaha yang bukan merupakan anak perusahaan atau cabang perusahaan yang dimiliki, dikuasai, atau menjadi bagian baik langsung maupun tidak langsung dengan usaha kecil atau usaha besar yang memenuhi kriteria sebagai berikut:

1. Memiliki kekayaan bersih lebih dari Rp. 500.000.000,- sampai dengan paling banyak Rp. 10.000.000.000,- tidak termasuk tanah dan bangunan tempat usaha; atau

2. Memiliki hasil penjualan tahunan lebih dari Rp. 2.500.000.000,- sampai dengan paling banyak Rp. 50.000.000.000,--

Berdasarkan ketentuan yang tercantum dalam Undang-Undang Republik Indonesia Nomor 20 Tahun 2008 tentang Usaha Mikro, Kecil, dan Menengah, kriteria dari usaha mikro, kecil, dan menengah dapat direkapitulasi seperti terlihat pada Tabel 1.

Tabel 1

Kriteria Usaha Mikro, Kecil, dan Menengah

\begin{tabular}{|c|c|c|c|}
\hline \multirow{2}{*}{ No. } & \multirow{2}{*}{ Jenis Usaha } & \multicolumn{2}{|c|}{ Kriteria } \\
\cline { 3 - 4 } & & Jumlah Aset & $\begin{array}{c}\text { Jumlah Penjualan } \\
\text { Setahun }\end{array}$ \\
\hline 1 & Usaha Mikro & maksimum 50 juta & maksimum 300 juta \\
\hline 2 & Usaha Kecil & $>50$ juta - 500 juta & $>300$ juta - 2,5 miliar \\
\hline 3 & Usaha Menengah & $>500$ juta - 10 Miliar & $>2,5$ miliar - 50 miliar \\
\hline
\end{tabular}

Sumber: Undang-Undang Republik Indonesia Nomor 20 Tahun 2008 tentang Usaha Mikro, Kecil, dan Menengah,

\section{Konsep Biaya}

\section{Biaya produksi}

Menurut Dunia et al. (2009) biaya produksi adalah biaya untuk mengubah bahan baku menjadi barang jadi. Biaya-biaya yang dikeluarkan dalam kegiatan manufaktur disebut biaya produksi (production cost atau manufacturing cost). Secara umum biaya produksi dapat dikelompokkan dalam 3 kelompok biaya, yaitu biaya bahan baku langsung (direct material cost), biaya tenaga kerja langsung (direct labor cost), dan biaya overhead pabrik (overhead manufacturing cost) seperti terlihat pada bagan di Gambar 1 .

Biaya bahan baku langsung (direct material cost) adalah biaya pemakaian bahan baku utama yang berhubungan langsung dengan produk yang akan diproduksi, di mana bahan baku tersebut umumnya akan menjadi bagian utama dari produk yang akan diproduksi. Contoh bagi pabrik konveksi yang memproduksi pakaian jadi, bahan baku utamanya adalah kain. Biaya tenaga kerja langsung (direct labor cost) adalah biaya yang harus dikeluarkan untuk membayar pekerja yang terkait langsung dengan proses produksi untuk menghasilkan produk jadi (Bustami dan Nurela, 2010: 12). Contoh biaya gaji bagian pemotong kain dalam perusahaan pakaian, gaji bagian persiapan, dan bagian penenunan dalam perusahaan 
pertenunan, dan gaji bagian produksi lainnya. Biaya overhead pabrik (overhead manufacturing cost) adalah biaya produksi yang dikeluarkan perusahaan selain biaya bahan baku langsung dan biaya tenaga kerja langsung (Rahayu, 2015). Biaya bahan penolong, biaya tenaga kerja tidak langsung, biaya sewa gedung pabrik, biaya penyusutan dan pemeliharaan mesin termasuk dalam kategori biaya overhead pabrik (overhead manufacturing cost).

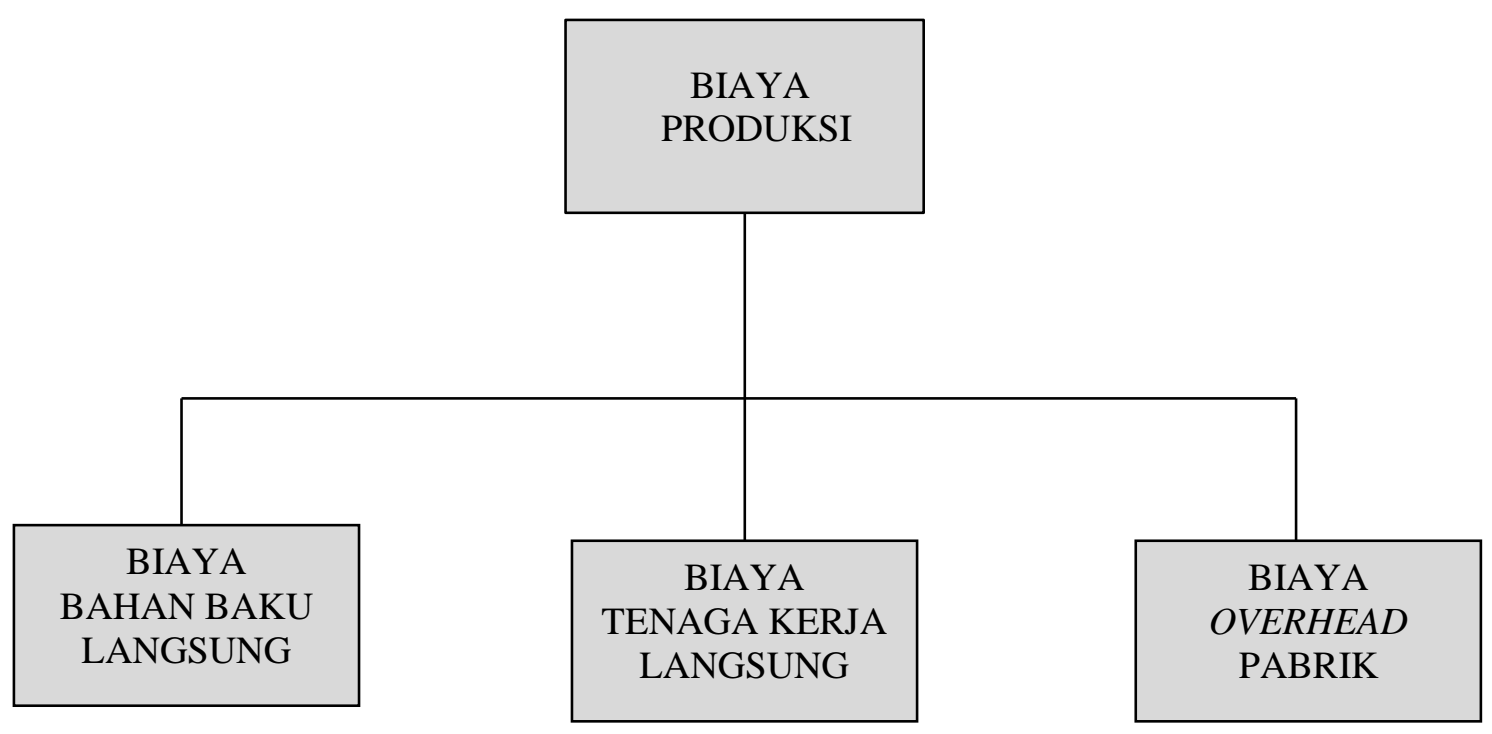

Sumber: Dunia et al. (2009)

\section{Gambar 1 \\ Elemen-elemen Biaya Produksi Klasifikasi Biaya}

\section{Biaya dalam Hubunganya dengan Fungsi Produksi}

Biaya produksi terkait dengan salah satu fungsi pokok perusahaan yaitu fungsi produksi. Biaya produksi ini sendiri terdiri dari biaya bahan baku, biaya tenaga kerja langsung, dan biaya overhead pabrik. Garrison et al. (2006) menyatakan bahwa penentuan standar biaya produksi dilakukan oleh manajer dan akuntan untuk menetapkan standar kuantitas dan biaya untuk setiap input utama. Standar kuantitas dapat menentukan banyaknya input yang dibutuhkan untuk setiap unit produksi.

Penentuan biaya produksi standar akan terdiri dari biaya bahan baku standar, biaya tenaga kerja langsung standar, dan biaya overhead pabrik standar. Setelah ditentukan standar untuk biaya bahan baku standar, biaya tenaga kerja langsung standar, dan biaya overhead pabrik standar, maka selanjutnya pengeluaran realisasi dari biaya bahan baku, biaya tenaga kerja langsung, dan biaya overhead pabrik akan dikontrol berdasarkan biaya standar yang telah ditetapkan untuk masing-masing elemen biaya produksi. Umumnya penggunaan biaya produksi standar bertujuan untuk mengendalikan agar tidak terjadi pemborosan pengeluaran untuk masing-masing elemen biaya produksi tersebut. 
Perusahaan yang menggunakan biaya standar, maka setelah terjadi realisasi dari biaya bahan baku langsung, biaya tenaga kerja langsung, dan biaya overhead pabrik akan dilakukan pengukuran selisih atau deviasi yang terjadi antara realisasi biaya biaya bahan baku, biaya tenaga kerja langsung, dan biaya overhead pabrik dengan biaya bahan baku standar, biaya tenaga kerja langsung standar, dan biaya overhead pabrik standar. Selisih yang terjadi bisa berupa selisih yang menguntungkan atau selisih yang tidak menguntungkan. Selisih yang menguntungkan terjadi jika biaya yang terealisasi lebih kecil dari biaya standar yang telah ditetapkan, sedangkan jika biaya yang terealisasi lebih besar dari pada biaya standar yang telah ditetapkan, maka terjadi selisih yang tidak menguntungkan.

\section{Harga Jual Produk}

Masalah penentuan harga jual produk biasanya merupakan masalah yang sangat krusial bagi setiap perusahaan. Penetapan harga jual produk yang terlalu rendah dapat menyebabkan perusahaan menderita kerugian. Sebaliknya jika harga jual yang ditetapkan terlalu tinggi akan menyebabkan produk yang dijual oleh perusahaan tidak laku di pasaran karena harga yang ditetapkan tidak kompetitif dan terlalu tinggi bila dibandingkan dengan harga jual yang ditetapkan oleh kompetitor perusahaan. Penentuan harga jual suatu produk merupakan suatu keputusan yang dibuat oleh manajemen tentang hal-hal yang perlu dibebankan kepada produk atau jasa (Horngren et al., 2008: 494).

Harga jual umumnya ditentukan berdasarkan biaya produksi ditambah dengan laba yang diinginkan. Penentuan harga jual dapat dilakukan sebagai berikut: 1. Menghitung total biaya produksi dengan menjumlahkan semua biaya produksi yang dikeluarkan, terdiri dari biaya bahan baku langsung, biaya tenaga kerja langsung, dan biaya overhead pabrik.

2. Setelah diperoleh total biaya produksi selanjutnya akan dihitung biaya produksi per unit dengan membagi total biaya produksi dengan jumlah unit yang diproduksi.

3. Harga jual per unit akan ditentukan dengan menambah biaya produksi per unit dengan laba per unit yang diinginkan.

Contoh perhitungan penentuan harga jual per unit yang diproduksi adalah sebagai berikut: misalkan PT ABC untuk memproduksi 1.000 unit produk mengeluarkan biaya bahan baku langsung sebesar Rp. 25.000.000,-, biaya tenaga kerja langsung Rp. 15.000.000,-, dan biaya overhead pabrik sebesar Rp. 10.000.000,-. PT ABC menginginkan laba sebesar $15 \%$ dari biaya produksi. Harga jual produk per unit yang diproduksi dapat ditentukan sebagai berikut:

1. Total biaya produksi $=$ Rp. $25.000 .000,-+$ Rp. $15.000 .000,-+$ Rp. 10.000.000,$=$ Rp. 50.000.000,-.

2. Biaya produksi per unit $=$ Rp. $50.000 .000,-/ 1.000=$ Rp. $50.000,-$.

3. Harga jual per unit $=$ Rp. $50.000,-+(15 \%$ x Rp. $50.000,-)=$ Rp. $57.5000,-$.

\section{Penelitian Terdahulu}

Berikut ini adalah beberapa penelitian sebelumnya yang dianggap relevan dengan penelitian yang saat ini dilakukan: 
1. Martusa dan Nasa (2012) menyatakan bahwa peranan biaya standar yang terdiri dari biaya bahan baku, biaya tenaga kerja langsung, dan biaya overhead pabrik ternyata sangat membantu manajemen dalam usaha meningkatkan efektifitas dan efisiensi pengendalian biaya produksi.

2. Rahayu (2015) menyatakan bahwa pembebanan biaya overhead pabrik harus dimasukkan ke dalam perhitungan harga jual produk.

\section{METODE PENELITIAN}

Jenis penelitian ini berupa penelitian kualitatif dengan bentuk studi kasus pada home industry Arumanis yang berlokasi di Desa Belik, Trawas, Kabupaten Mojokerto. Menurut Sugiyono (2017: 8) metode penelitian kualitatif sering disebut metode penelitian naturalistik karena penelitiannya dilakukan pada kondisi yang alamiah (natural setting). Bentuk penelitian ini bersifat eksploratif yang artinya penelitian untuk menggali sebanyak mungkin informasi sehingga jawaban yang ditemukan terhadap masalah tidak bersifat ekslusif

Penelitian ini menggunakan jenis data primer. Data primer adalah data yang diperoleh secara langsung dari pelaku bisnis kripik Arumanis. Tahapan-tahapan untuk memperoleh data primer:

1. Observasi

Observasi dilakukan pada awal penelitian dengan mengunjungi lokasi dan obyek penelitian dan mengamati secara langsung.

2. Interview

Pengumpulan data dilakukan dengan wawancara secara langsung kepada pelaku bisnis.

3. Kuesioner

Cara pengumpulan data dengan membagi daftar pertanyaan yang dibutuhkan agar dapat memperoleh informasi yang bermanfaat dalam penelitian.

\section{HASILPENELITIAN DAN PEMBAHASAN}

Kegiatan ekonomi di Desa Belik pada umumnya dilakukan oleh usaha mikro yang mayoritas merupakan kelompok usaha makanan. Kelompok usaha makanan tersebut berawal dari usaha keluarga untuk menambah penghasilan atau pendapatan keluarga. Selain kelompok usaha makanan, penduduk setempat juga melakukan usaha lain seperti pertanian, perkebunan, perternakan, dan kelompok kerajinan.

Berdasarkan uraian di atas bahwa selama ini pelaku bisnis kripik Arumanis tidak melakukan pencatatan biaya produksi dan hanya berdasarkan taksiran. Peneliti mengambil contoh produk kripik pisang yang paling laris terjual. Perhitungan biaya produksi selama 1 bulan sebagai berikut:

1. Bahan baku langsung berupa buah pisang yang diperkirakan senilai Rp. 9.000.000,-

2. Upah tenaga kerja langsung yang dibayarkan untuk orang sebesar Rp. 3.000.000,- dengan masing-masing mendapat Rp. 750.000,-. Ada 4 tenaga kerja langsung yang di gunakan oleh home industry Arumanis.

3. Biaya overhead pabrik Rp. 1.500.000,-

Biaya overhead yang digunakan adalah minyak goreng, gas elpiji, air, gaji tenaga kerja tidak langsung, dan plastik kemasan. 
Perhitungan total biaya produksi:

$\begin{array}{ll}\text { 1. Bahan baku langsung } & \text { Rp. } 9.000 .000,- \\ \text { 2. Tenaga kerja langsung } & \text { Rp. } 3.000 .000,- \\ \text { 3. Overhead pabrik } & \text { Rp. } 1.500 .000,- \\ \text { Total biaya produksi } & \text { Rp. } 13.500 .000,-\end{array}$

Setiap bulan produk aneka kripik tersebut dapat terjual rata-rata 900 pak maka harus tersedia produksinya sebanyak 1.000 bungkus besar. Jadi perhitungan biaya per unit (bungkus besar) adalah:

Biaya per unit $=$ Rp. $13.500 .000,-/ 1.000=$ Rp. 13.500 per bungkus besar

Kripik pisang tersebut dijual dengan harga Rp. 16.000 per unit bungkus besar secara grosir dan jika penjualan dilakukan langsung ke konsumen di daerah Trawas maka ukuran bungkusnya lebih kecil seharga Rp. 8.000,-. Penentuan harga jual yang dilakukan oleh home industry Arumanis berdasarkan harga pasar, tidak berdasarkan perhitungan harga pokok. Hal ini dilakukan agar produk yang dijual dapat bersaing dengan kompetitor.

Keputusan penentuan harga jual produk kripik pisang sebaiknya dilakukan dengan cara yang lebih bijaksana. Keputusan penentuan harga jual kripik pisang akan mempengaruhi kualitas produksi kripik dan harga jual kripik sehingga dapat memengaruhi pendapatan yang diterima oleh home industry Arumanis serta biaya yang dikeluarkan oleh home industry Arumanis. Harga jual yang ditetapkan harus bisa menjaga kelangsungan hidup dari home industry Arumanis, dapat memaksimalkan laba, menjamin mutu produk, meningkatkan penjualan, mempertahankan dan memperluas pangsa pasar, serta menstabilkan harga (Bahri dan Rahmawaty, 2019).

\section{SIMPULAN}

Perusahaan kripik Arumanis menjual produk kripik hanya berdasarkan harga pasar mengingat kompetitor semakin banyak. Perhitungan biaya produksi yang dilakukan oleh home industry Arumanis terhadap produk kripik pisang hanya berdasarkan taksiran karena keterbatasan pengetahuan dan masih dilaksanakan secara sederhana. Kondisi yang selama ini dijalankan oleh pelaku bisnis kripik Arumanis masih dapat diterima sesuai dengan pasar lokal.

\section{SARAN}

Home industry Arumanis perlu menghitung secara tepat biaya produk dan laba yang akan diperoleh agar perhitungan harga jual relatif lebih akurat. Perhitungan biaya produksi terhadap aneka produk terutama produk kripik pisang yang paling laris terjual perlu diperhitungkan secara teliti agar pelaku bisnis dapat mengetahui harga produk yang real dan perencanaan laba. Untuk mengantisipasi kondisi yang akan datang, maka home industry Arumanis perlu memperhatikan kualitas produk dan jangkauan saluran distribusi yang lebih luas tidak saja terbatas di daerah Trawas. 


\section{DAFTAR PUSTAKA}

Bahri dan Rahmawaty. 2019. Analisis Penentuan Harga Pokok Produksi dalam Menentukan Harga Jual Produk (Studi Empiris pada UMKM Dendeng Sapi di Banda Aceh). Jurnal ILMIAH Mahasiswa Ekonomi Akuntansi, Vol. 4, No. 2, pp. 344-358.

Bustami, B. dan Nurlela. 2010. Akuntansi Biaya. Yogyakarta: Graha Ilmu.

Dunia, Firdaus Ahmad, Wasilah Abdullah, dan Catur Sasongko. 2009. Akuntansi Biaya. Jakarta: Salemba Empat.

Garrison, Ray H., Eric H. Noreen, dan Peter C. Brewer. 2006. Akuntansi Manajerial. Edisi Kesebalas. Jakarta: Salemba Empat.

Horngren, Charles T., M. Datar, and G. Foster. 2008. Akuntansi Biaya, Penekanan Manajerial. Jakarta: Erlangga.

Juliprijanto dan Prasetyanto. 2020. Potensi Usaha Kecil Mikro dalam Meningkatkan Pertumbuhan Ekonomi. Jurnal Riset Ekonomi Pembangunan, Vol. 5, No. 1, pp. 97-117.

Kusuma. 2012. Analisis Kelayakan Finansial Pengembangan Usaha Kecil Menengah (UKM) Nata Decoco di Sumedang, Jawa Barat. Jurnal Inovasi dan Kewirausahaan. Vol. 1, No. 2, pp. 113-120.

Manurung, Adler Haymans. 2008. Modal untuk Bisnis UKM. Jakarta: Buku Kompas.

Martusa, Riki dan Lim Ade Nasa. 2012. Penerapan Biaya Standar Terhadap Pengendalian Biaya Produksi. Akurat Jurnal Ilmiah Akuntansi, No. 7, pp. 1-20.

Mulyadi. 2012. Akuntansi Biaya. Edisi 5. Yogyakarta: UPP-STIM YKPN.

Rahayu. 2015. Analisis Pembebanan Biaya Overhead Pabrik Terhadap Harga Jual Produk pada UKM di Wilayah Sukabumi. Ecodemica, Vol. 3, No. 2, pp. 551560 .

Sarwoko, Endi. 2017. Strategi Pertumbuhan Usaha Kecil Menengah (UKM). Jurnal Ekonomi Modernisasi, Vol. 13, No. 1, pp. 46-52.

Sugiyono. 2017. Metode Penelitian Kuantitatif, Kualitatif, dan R\&D. Bandung: CV Alfa Beta.

Undang-Undang Republik Indonesia Nomor 20 tahun 2008 tentang Usaha Mikro, Kecil, dan Menengah (UMKM). 